УДК 2:168.1

\title{
On Universal Definition of Religion
}

\author{
Daniil V. Pivovarov* \\ Ural Federal University \\ 51, Lenin Str., Ekaterinburg, 620083, Russia
}

Received 30.10.2014, received in revised form 15.11.2014, accepted 06.12.2014

Eclecticism, sophistry and dialectics as methods of determining the essence of religion are mutually compared. It is proved that the definition of V. S. Solovyov - "religion is a human relationship with the Absolute"- is universal and meets the requirements of dialectics. It is proposed that there are the objective and subjective levels of religiosity. With respect to the subjective religiosity the author defines religion as a form of individual and public consciousness which sacralizes the human relationship with the Absolute. The main question of any religion, based on this definition, is formulated.

Keywords: eclecticism, sophistry and dialectics, the V. S. Solovyov's definition of religion, the Absolute, objective and subjective religiosity, the basic question of religion.

Research area: philosophy.

\section{Trends of eclecticism and sophistry in the scientific analysis of the essence of religion}

Three general alternative methods eclecticism, sophistry and dialectics - are broadly applicable in the scientific search. The problem of constructing a universal definition of religion is a stumbling block in philosophy of religion. For whatever reasons, to solve this difficult problem some religious scholars choose eclecticism, the second - the method of sophistry, and others - dialectics as the antithesis of eclecticism and sophistry. As it is known, the term "eclecticism" means not following one style or set of ideas but choosing from or using a wide variety. The eclectic method requires considering many aspects of the studied phenomena, and this requirement enclosed undeniable epistemic virtues of eclecticism. Disadvantages of eclecticism, according to its critics, are primarily in the fact that it unites artificially disparate facts and ideas, evaluates them as equally important, and it does not emit the most important feature of the studied object.

A scientist-sophist, in contrast, selects from the many features of his subject only some one sign, and he declares that it is unconditional, principal and leading. However, opponents soon discover that the sophistically absolutized feature, in fact, turns out to be random, unimportant and secondary. The method of dialectics combines the principle of comprehensive analysis of various aspects of the investigated thing and the requirement to record a genuine "critical link", i.e. the most important feature of this thing. Thus, dialectics peculiarly synthesizes scientific dignity of eclecticism and sophistry.

(C) Siberian Federal University. All rights reserved

* Corresponding author E-mail address: daniil-pivovarov@yandex.ru 
J. Smith's concept of religion (University of Chicago) can serve as a typical example of the eclectic orientated method. The American scientist suggests instead of the theme of ontological essence of religion to study another, taxonomic, theme of classification of religions, since the actual religious behavior does not seem to theoretical construct "religion"(Smith, 1998). However, we should not be unconditionally agree with Smith's proposal, as a well-known logic-methodological rule states that any correct classification should be based only on a single logical basis; "summative" classification based on different logical grounds is invalid.

Many Russian scholars of religion, just as J. Smith, believe that it is futile to try to show the essence of religion in any one general definition through a traditional indication of typical and special differences. In their view, in contrast to the useless pursuit of a unified definition of the essence of religion it would be more fruitful to collect and combine many definitions of various aspects of religion, namely, to list the different definitions of religion, which originally operate with philosophers, sociologists, psychologists, culturologists, ethnologists and others. For example, proponents of this methodological approach proposes to include into the "complex" definition of religion judgments that religion: (1) in its essence is social (but is unlikely to be, for instance, W. James would agree with this); (2) is a subsystem of any society; (3) depends on the material production; (4) is the way to overcome human alienation; (5) reflects reality through the prism of suppression and dependence; (6) is a cultural phenomenon (Yablokov, 2005).

The above features are undoubtedly the aspectual predicates of "religion", and they in fact are, to varying degrees, in real religions. However, the exact same features can be found in many other forms of social consciousness. In that case, how can we fundamentally distinguish religion from mythology, art, morals, etc.? What is the reliable criterion for the recognition of and registration any "religious organization" the criterion which, for example, an official of the Ministry of Justice must have? The named "complex" definition of religion does not satisfactorily answer these reasonable questions. It does not include the requirement to allocate "the major and decisive link". Consequently, the process of constructing such a definition as a whole fits exactly in the scientific paradigm of eclecticism. This approach, again, has a tangible scientific value, but, nevertheless, it is only prolegomena to any future universal definition of religion.

It is important to note that a fairly wide use of the method of eclecticism in the scientific study of religion is due to particularly complicated circumstances of philosophical and ideological pluralism, which make it very difficult to build a definition of religion through some generic concept and species differences. The definition of religion by enumerating many aspects of all religion, is, in particular, caused by the tolerant intention to optimally take into account existing realities of religious studies and disagreements. However, we still try to go the traditional route and look for a single essential definition of the concept of religion in accordance with the rules of formal logic.

I guess the question about the very essence of religion is, first of all, the fundamental problem of philosophy of religion (but not of sociology of religion, of culturology of religion, psychology of religion, etc.). According to Christian metaphysics, the essence of religion is metasocial, because the transcendent God is the source of religion. On the contrary, in the light of Marxist philosophy the essence of religion is social, because Marxists understand religion as a universal product of human imagination and specific socio-economic conditions. The worldview confrontation 
between alternatives of objective idealism and materialism - the main reason for the polarity of solutions to major religious issues and irremovable religious pluralism in ontology of religion.

Philosophy of religion, as the worldview core of Science of religion, constantly strives to abstract universal definition of religion, which generalizes the maximum symptoms of a wide variety of cults and confessions. Unlike philosophers, theologians deliberately bottom of their analysis in the narrow terms of Theism and offer a more concrete concept of religion, adapting it to their own faith apology. For example, an apologetic Christian theology understands religion not just as a "relationship with the God", but as a kind of faith in the God, which certainly is inscribed in the uniqueness of Christian message.

We repeat that in scientific study of religion the way of sophistry is an opposition to eclectic way of knowing the nature of religion. A sophist intends theoretically to abstract the only one and the most important sign of religion "in general". $\mathrm{He}$ is not much interested in the empirical principle of "comprehensiveness". However, the "universal" definition of religion, formulated on that logical basis which the sophist sought out, does not maintain professional theological criticism. "The main feature" that he found, actually turns out to be not the most important feature of any religion, or it is just a pure game of his mind. Sophistic definitions of religion most often occur due to logical errors of either too narrow or too broad definitions.

The traditional European definition of religion as "belief in the God or gods" is a typical example of the error called "a too narrow definition of a term", because it is not suitable for a great variety of non-theistic religions (say, classical Buddhism or Taoism). And besides, religion is not only a particular faith, but also a sort of special knowledge. Another example of sophistic inventions - the definition of religion as «a belief in supernatural»; for example, Marxist atheism prefers to use this definition.

Let's list (in addition to the mentioned above) the most widespread sophistic definitions of religion that are based on voluntary or involuntary logic errors of broad or narrow definitions of religion. Religion is:

- a sense of human dependence on the infinite (F. Schleiermacher);

- symbols of primitive myths about the nature (M. Müller);

- faith in invisible spiritual beings (E. B. Tylor);

- personification of powerful natural forces and request for mercy (J. Fraser);

- fantastic reflection in the form of unearthly forces such external circumstances that prevail over man (L. Feuerbach, F. Engels);

- a sense of the sacred (J. Huxley); the relationship with the Holy (R. Otto); «the experience of the sacred» (J. Wach);

- universal obsessional neurosis in the form of protection from feelings of internal uncertainty and fear (Z. Freid);

- ritual cultivation of socially accepted values (J. Fischer);

- cosmically correct dispensation of own spirit (M. O. Gershenzon);

- faith in destiny (D. B. Pratt);

- system of truths that is able to alter the character of that human being who recognizes it (A. N. Whitehead);

- aspiration to defend at any cost universal value of a particular ideal (J. Dewey).

And these are not all of the common sophistical formulas of religiosity of a person. The author of each of these formulas summarized facts intuitively attributable to one or another aspect of religion, and there are no sufficient scientific reasons (if not to take into account the political-ideological considerations) to discard 
any of them as absolutely erroneous. But probably the real contradictory essence of religion cannot be reduced to any of the above-mentioned definitions.

"Essence" (lat. essentia, i.e. concentration of being), which the dialectical theory understands as an infinite set of internal capabilities and relationships, is extremely mobile, and any component of essence can be decisive in a particular stage of its materialization. The listed definitions of religion, if you take them together in their varying proportions and mutual transitions, refer to the level of essence of religion which has already been studied by scientists. In our opinion, the philosophical definition of religion's essence is required in order to express this level in the most general form. The definition of this kind is capable to reflect dialectically within itself all those private and controversial definitions which we have already mentioned. An educated and thoughtful reader will easily find that the listed definitions of religiosity of humans are products of infinite extrapolation and broad formulas of religion, or, on the contrary, they are based on the error of a too narrow definitions. But it is much difficult to uncover the sophistic character of the definition of religion as "belief in supernatural", so let's discuss and critically evaluate this popular definition in more detail.

\section{Sophistic character of the definition of religion as «belief in supernatural»}

Many people frequently say about religion as a belief in supernatural being of special creatures, things or relationships to them. But what is supernatural? Is it something "beyond all being"? Or is it "beyond any existence, determinate being, and created nature"? Some philosophers define «supernatural» using such concepts as "supersensible", "nonphysical", "unextended existence" - as something not detectable by external human senses and instruments. Others give it a more narrow sense: supernatural is a particular hypothetical measurement of another space in which souls can live without earthly bodies ("afterlife world").

Many analysts still avoid the concept "supernatural" because of the paradoxical nature and vagueness of its meaning. In European culture, a specific idea of supernatural, probably, dates back to Plato's and especially Neo-Platonist Plotinus's understanding of the term "One ": the Oneness is over being, super-truth, and therefore it is illogical to say that it has "being". The source of all things, for Plotinus, is the One, which is above every "is". Being is derived from the Oneness, which is not the primary but the secondary reality. It turns out that it is inaccurately to call the unmanifested God "Whoever is" because God is "supernatural". The term "to be" should be used only to refer to the creation and manifestation of the God. "The God " means" the One, and "being" is a product of creativity of the God. Plotinus's concept is logically inconsistent, since in it: a) "the oneness" artificially separated from the merged "many"; b) the unmanifested "the One" was originally declared non-existent and not having its direct being, so it's impossible to argue that there is the God or to deny this.

There are many Plotinus's followers among heterodox Christians. Perhaps their logically meaningless judgment that the God is "the supernatural beginning of all things" (contrary to the holy books of all monotheists), goes back to Plotinus's conception. Curiously, many atheists do their critical work easier when they define religion as a false belief in supernatural and do not find any real content in the notion "supernatural". Their criticism is aimed at a non-existent thing, i.e. pointless.

Typically, reference books define "supernatural" as something staying over the material world, the world of changes, and 
does not obey the laws of physical nature. It is believed that the material world is the antipode of the non-material world. Does this mean that "supernaturalness" is attributed to the intangible world - to the world of objective ideal essences or subjective world of consciousness? The world of intangible objective entity, by definition, does not obey the laws of physical changes; it is deathless, changeless, and motionless. But one can hardly say that "supernatural" means "metaphysical". According to Aristotle, the super-physical being, at least potentially (in the sense of "pure forms") has some kind of being.

The subjective world of human consciousness also cannot be described in terms of physical science and explained as the scope of action of the laws of mechanics, optics and electrodynamics. However, modern physics has expanded understanding of the forms of objective existence, when introduced the concept of virtual (non-metric, non-extended) phenomena. The general theory of systems operates with the idea that the total property of each system is not localized anywhere and in this sense it is immaterial.

System property, information, functional existence, virtual processes - all these concepts are not described by the theory of substance and field, but at the same time they are included in the general concept of "objective physical existence", which by its general scientific sense is much broader than that of the material world. It turns out that physical reality includes not only material but also intangible objective existence of virtual processes and changes.

"Virtual-physical" adequately meets the definition of "supernatural". Notions of metaphysical being, subjective existence and physical existence are applicable in philosophy. None of the philosophers would think, for example, to refer the term "supernatural" to human consciousness. "Metaphysical", from the point of view of philosophy, is the highest form of existence, but not supernatural, not over being. Names of the God in the Bible or the Koran mean true being, but not non-being or over being. It is impossible not only to think but even call super-truth, super-perfectness, super-deity. In fact, none of real religions is based on faith in "supernatural".

Artificial is the logical antithesis of natural. But whether it is reasonable to refer supernatural to artificial? First of all, artificial is physical, which was converted by a man, and it has a predicate of existence, i.e. is not supernatural. Consequently, the notion of supernatural is an empty concept, a fiction, for materialists and idealists. People turn to this concept for purely psychological reasons, when they find themselves in conditions of impossibility to express the idea of the God. The God is "not similar" to any of the known forms of existence. The God transcends so that seemingly easier to say: "He is supernatural, after all this, beyond all something, meta-real, etc.". However, when it is difficult to describe some vague phenomenon, we often obscure terminology fixing the object of unclear thoughts by adding to the previously known terms such prefixes as: 1) "over" or "above" (e.g., superman), 2) "after" (e.g., post-capitalism), 3) "outside" (extra-sensor), 4) "quasi” (quasi-elastic).

To enable a logical difficulty contained in the notion of super-being some philosophers quietly replace terms "is" or "existence" by "nature" and say: super-being is the same as supernatural. The English word «supernatural» in Russian means "super-being". As a result, more even confusion becomes. Natural - is something related to the original genotype (to the Old Slavonic god named "Rod"), generic start. If you believe that the God is the Father and the ancestor of all visible and invisible forms of cosmic laws of the universe, it is logically inconsistent to speak of the God as something supernatural without distinguishing 
between concepts such as "creative nature" (in Latin - natura naturans) and "created nature" (natura naturata).

Historically, the term "nature" includes a sense of something hidden, extrasensory, internal ("what grows by itself "), although modern everyday thinking assigns this term a meaning "to be a surface": nature - is what surrounds us, what we see around. Usually the word "nature" refers to either the original essence (core) of a thing, or the totality of things, untouched by human beings. Pantheism identifies the God with nature and monotheism separates and opposes these realities. The word

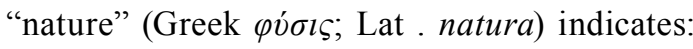
1) all non-artificial - what is revealed of itself, like revealing a rosebud, and grows by itself, beyond the power of people (the growth of plants and animals, rampant elements, move the stars, the cycle of the seasons, etc.), 2) putting oneself out of mysterious enigma and turning itself into an independent unit; 3) also that grew up in the process of spontaneous growth; 4) the internal law of things, its essence.

"The nature of visible things" is a general notion whereby ancient materialists designated invisible atoms, elements, primary particles; idealists taught that the divine or objectiveideal nature is the basis of the observable world. Progress in medieval theology occurred when two special concepts within the general concept of nature were distinguished - creative nature (not born, the first) and created nature (the generated, physical). Creative nature (the God) is endowed with being, and created nature - with existence; the God is beyond any existence, but He is. "To be" does not mean to be located in any place at present time. The spirit blows where it wants. The spirit is omnipresent and eternal, timeless, being. The law of created nature is omnipresent only within the field of physical existence. John Scotus Eriugena $(810-877)$ distinguished four natures: the creative and uncreated; created and not creative; created and creative; uncreated and not creative.

So, apparently, there is only one reasonable way to justify the metaphor-pseudo concept "supernatural" - to define "supernatural" by contrasting the creative and physical (created) nature. "Supernatural" - is that does not physically exist and has the firstborn (first-natural) being; this quasi-notion means liberation from created limitations and necessity of subordination. The God is "supernatural" only in this specially stipulated and extremely narrow sense and religion as a relationship with the God presupposes faith in "supernatural". If to accept the definition of religion as "a faith in supernatural" as the general and essential definition of religion, it should be assessed as sophistry.

Is it possible in philosophy of religion to deduce such generalizing and unifying formula that would dialectically pack in itself a variety of definitions of different aspects of religion definitions which exist in religious studies? Many modern scholars of religion do not believe in the possibility of such generalization, mindful of former mistakes and hasty naive generalizations in religious studies and calling for caution. Perhaps, those are right who are guided by the principle of "to watch more and more, and to generalize less and less" (A. Poincare)? Nevertheless, I believe that it was Vladimir Solovyov, the great Russian philosopher, who suggested and substantiated well the desired integral formula of the very essence of religion that meets the spirit of the dialectical method and overcomes the disadvantages of the eclectic and sophistical definitions.

\section{V. S. Solovyov's dialectical definition of religion}

First of all, let us refer to Solovyov's work "Reading about the God-manhood" and discuss the idea developed in it about the 
deepest essence of any religion. V. S. Solovyov writes: "Religion, in general and abstraction, is a connection between a man and the world with the absolute beginning and focus of all existing things", "Religion is the reunion of a man and the world with the unconditional and wholehearted beginning..." (Solovyov, 1969). In philosophy, "the unconditional beginning of everything existing" is indicated by the Latin term "Absolutus"; in other words, religion is a relationship between a man and the world with the Absolute. This formula, developing L. C. F. Lactantius's tradition («religio is a relationship with the God"), is amazingly versatile and suitable for the description of all types of religion - cosmocentric, sociocentric and egocentric (Pivovarov, 1998).

Nicholas of Cusa, M. Mendelssohn and F. Jacobi, J. G. Fichte, F. W. J. Schelling, G. W. F. Hegel, and etc. contributed to the wide dissemination of the concept of "the Absolute" in Philosophy. Gradually, this concept has become a separate category, which implicitly compiled the following universals: the God, Brahman, Spirit, Tao, Logos, pure Being, Oneness, apeiron, Nous, Ein-sof, all, substance, universal substrate, immeasurable, unknowable, abyss of being, goodness, maximum and minimum, the Monad of monads, matter, etc. Some thinkers define "the Absolute" as the infinite Spirit, which is the first principle - eternal, unchanging, allperfect and incomprehensible. Others speak of the Absolute as the eternal material substance, self-develops from one perfection to another perfection and partially knowable by man. Philosophers mean by "the Absolute" either transcendent or immanent Fullness of Life (Pleroma). As you can see, this category (the "Absolute") generalizes to the maximum extent and dialectically accommodates archetypal representations of all past and present religions and philosophical systems.
We can identify at least seven religious images of the Absolute appearing in cosmocentric religions:

1. The God as a person (Judaism, Christianity, Islam, theistic traditions in Hinduism).

2. Impersonal transcendent Being as the absolute source of all existence (Brahman in some currents of Hinduism, Tao in the Chinese tradition, the One without Attributes in the Sikh religion, Tathagata in the Mahayana).

3. The Absolute, inherent in every human being (the eternal Atman in Hinduism, Enlightened Mind in Buddhism, omnipresent Holy Spirit in Christianity).

4. The Ultimate Goal (nirvana in Buddhism, Paramatman, i.e. pure soul, in religion of Jainism).

5. The heavenly constellation of gods reaching a common goal (kami in Shintoism, Taoist deities, vacan in the Sioux Indian myths, spirits in religions of American Indians).

6. The Absolut, erected on the basis of revelation of the founder of a religion (Dharmakaya - an image of the eternal cosmic Buddha, eternal cosmic Christ on the heavenly throne).

7. The Absolute as the universal eternal law (Dharma or Rita or Hinduism, Tao in Taoism, Dhamma in Buddhism, Word-Logos in Christianity, Torah in Judaism).

Logically different images of the Absolute can be combined with each other in one the same historical religion. Typology of the Absolute can be developed further, including in it the sacred ideals of civil and egocentric religions. It is possible to survey systematically manifestations of the ideological side of religious process if to combine this typology with the main question of religion. Every religion gives the Absolute different names: the God, Central Energy, Superman, Generic "I", absolute "I" in my empirical "I", Sun, fire, etc. You can build a set of correct and useful scientific 
classifications of religion based on the definition of religion, which Solovyov formulated.

Thus, the category "the Absolute" as a part of Solovyov's definition is similar to the logical-mathematical variable $X$, instead of which it is possible to substitute whenever any less general concept. It is easily seen that this definition anyway summarizes and dialectically synthesizes the following inaccurate definition of religion: 1) the relationship with the God; 2) belief in the supernatural; 3) a sense of dependence on infinite; 4) symbols of primitive myths about nature; 5) faith in the invisible spiritual beings; 6) personification of the forces of nature; 7) fantastic reflection of the forces that dominate over men; 8) sense of the sacred; 9) belief in fate and also definitions of Z. Freud, D. Fischer, M. O. Gershenson, A. N. Whitehead and J. Dewey. Therefore, V.S. Solovyov, first, thoroughly analyzed different aspects of religion, each of which has already found its reflection in the corresponding one-sided formula. Secondly, the Russian thinker dialectically summarized these different formulas and showed that religion is just "man's relationship with the Absolute" relationship that is only established or which has been consolidated already and has reproduced from generation to generation.

Does modern natural science confirms faith in the objective reality of the Absolute and man's dependence on the Absolute? For the case of pantheistic religion, V.S. Solovyov's definition can be verified using the following induction-metaphor. Our planet tends to the Sun, the solar system attracts to the center of our galaxy, the latter - to the more energetic center of metagalaxies, and astrophysics today also hypothesize the existence of the extremelypowerful center of super-metagalaxies. So, according to scientific data, in the universe there are a number of non-absolute centers of all existing increasing in terms of their power. Consistently arguing we can hypothetically conclude that the extremely powerful and unconditional center of the universe should be, to which all the invisible threads of being probably converge. However, it is unlikely that science ever can really open it.

Model of the solar system can serve as a geometric analogy for pantheistic Almighty Deity: planets revolve around the Sun, each of them accompanied by the centripetal and centrifugal forces. The first force is aimed at preserving the integrity of the entire system (a metaphor for good, the Goodness?). The second is trying to disrupt the planet from its orbit, alienate it from the Sun (the forces of evil?). Cult of the Sun originated not accidentally, as well as centripetal and centrifugal tendencies were personified in human images of the God and Satan. Of course, in the light of modern astronomical knowledge, the proposed model is incomplete and inaccurate, and the centrifugal force may have a different explanation - for example, as the attraction of the planet to the space center which is more powerful than the Sun. Then, extending this model to the image of metagalaxy, we are able to interpret the nature of polytheism (hierarchy of worldly gods) geometrically, metaphorically.

\section{Objective and subjective religiosity}

I suppose that Solovyov's definition gives us the ability to identify theoretically the following two levels in pantheistic religion of cosmocentric type: levels of objective and subjective religiosity. At the level of objective religiosity a person does not realize the reality of his relationship with the Absolute. Objective religiosity often is not represented in picturesque images or symbols of consciousness. It has a latent character, exists in the unconscious form or informs about itself only through direct knowledge (for example, via intuition). But sometimes an individual becomes aware of his objective religiosity. No wonder that one proverb says: "A peasant will not cross himself 
while the thunder will break», and the following saying makes a transparently clear sense: "There are almost no atheists in trenches". At the level of subjective religiosity people anyway, realize or deny their relationship with unconditional cosmic beginning.

In my opinion, religious scholars had never noticed the possibility of this conclusion: there was no such classification of levels of religion in the scientific literature, and the problem of unconscious and conscious religiosity almost did not rise. Is religion the only one of the forms of individual and social consciousness, or we can also refer religion to forms of collective unconscious in human psyche and study its hidden archetypes?

Undoubtedly, humanity as a whole and each of us individually (as well as any particle of the world order) are objectively connected with the original and ultimate space center, although many of us are not aware of this fact. If space is infinite, then it is possible to implant its center at any point in our universe. The everywhere acting law of attraction finds its theoretical explanation and meaning in the pantheistic idea of "objectively real religiosity of everything". Is it because any limited being has a tendency to self-expansion, to cross its borders and expand indefinitely? Is it because people are experiencing inescapable existential craving for permanent improvement of their environment? Is it because many pantheists claim that religious feeling is inherent to men?

This view is also shared by supporters of the doctrine of the transcendent Absolute. According to G. Simmel, one of the founders of sociology of religion, all people have the need for religion, which quenches only faith in the transcendent; to satisfy this need, "godly-devout people" do not experience any problems, and godless people seriously are concerned with the definition of their relationship to the transcendent: "Who does not have the God in himself, he must have the
God outside"(Simmel, 1996). V. Frankl, a famous psychologist, argues that people unconsciously always tend to the Absolute - to "the unconscious God"(Frankl, 2000).

Another case - religion of a subjective order, i.e., awareness and dogmatic description of people's connection (or disconnectedness) with the Absolute. When people talk about any particular religion, they usually have in mind some subjectively recognized denomination. The convinced theists, pantheists, panenteists, and atheists appear exactly at the level of subjective religiosity. The hidden core of religion is unconscious religiosity of a person, i.e., his mystical aspiration to the Absolute. Concepts of objective and subjective religiosity have no place in the works of V. S. Solovyov himself. However, the meanings behind such concepts can be "deducted" from his general idea of religion.

Human search for the Absolute never stops; people are motivated by the idea of absolute reality in all spheres of their activity. I repeat, only the supporters of religious or atheistic pantheism can share the assumption that the Absolute resides in the physical world. Deists and theists, who believe in the transcendent Absolute, are not likely to join this ontic hypothesis. For example, Newton thought that the God dwells in transcendental absolute space - in sensorium Dei.

In this objective and pantheistic sense, there are no purely secular (non-religious) human beings. All of us without exception are involved in communications - energy, material and informational - with the immanent and absolute center of all existing. Not only the waves emanating from a plurality of radio sources in the world penetrate us, but also much more powerful waves emitted from the hierarchy of cosmic centers (the Sun, the Milky Way, etc.) get us. However, not all of us know about this circumstance, and some people even at all, contrary to common sense, deny the reality of their relationship with 
the focus of cosmic forces - they say, there is no hierarchy of cosmic energy centers and nothing absolute in nature does happen.

Connections between sacred objects of terrestrial origin and unearthly forces are not always mentioned in some sociocentric religions (fetishism, totemism, special cults of a leader, etc.). But Solovyov's definition also applies to the analysis of civil religions, many of which see "the absolute principle and center of all that exists" in the past earthly archetype (the golden age, totem proletarian leader), or in the future state of mankind (the kingdom of reason, communism). Solovyov's definition can also be used for the analysis of egocentric religions in which «the absolute principle" was laid inside an individual person.

Thus, Solovyov's definition of religion is universal, it has a dialectical character and, in my opinion, this definition should be the most preferred. At the same time, I propose to clarify this definition, taking into account the hypothesis, which was discussed above, about the objective and subjective levels of religious relationship to the world. First, taking into account the already established tradition, it is more reasonable to understand "religion" as not any connection with the Absolute, but only as person's subjectively experienced connection with the Absolute. Secondly, the concept of subjective religiosity needs to be strengthened by adding to it the more specific concept of "sacred relationship to the world". We now formulate a revised synthetic definition of the essence of subjective religiosity: religion is such a form of individual and social consciousness, which gives the sacred character to the connection between a man and the Absolute.

\section{The main question of religion}

Whether it is possible to formulate briefly the main question of any religious relationship to the world if to start from Solovyov's universal definition of religion? I think, it is possible. Apparently, every religion involves answers to the following three fundamental questions:

1. Is there supersensible reality, which subjugates the whole intuited world order of things, and what is the greatest in the world its revealed side or, conversely, the world's side which is hidden from us?

2. If supersensible reality has an objective existence, then how we, who are bodily belonging to the sensible world, can know about it?

3. Is the supersensible world open to us through the signs of ordinary things; whether it is embodied in the chosen person, in his behavior and words; or this supersensible world is given in the form of laws of nature and society that are speculative, but invisible?

But are these issues specific only for religious consciousness? Moreover they are formulated in the language of Philosophy. Not only theologians, but also philosophers, naturalists, artists, politicians, and lawyers formulate these questions in one form or another. The problem of correlation among phenomenon and essence is one of the ontological expressions of the basic question of philosophy. Scientists see the crucial task of science in the opening supersensible links between things, among processes - scientific research aimed at the "ghost" of an objective law of nature.

Likewise is the case in art. Hegel defined art as a sensuous manifestation of an idea (essence) and wanted to grasp the main question of art in finding ways to overcome the fact that universe is divided into the ideal world and the real world. Art helps people to eliminate fear of the unknown essential forces of being, when it embodies hidden essences in perfect sensual forms. Humanists and social scientists peer into the depths of human and social life 
and trying to unravel the secret laws of growth of humanity. Perhaps all basic forms of social consciousness initially involve the same triad above the mentioned problems, although every time and separately formulate them in their specific language.

Language of theology and philosophy, which we had to use in the previous discussion, is the most suitable language for detecting identity and diversity of formulations of these fundamental problems of human existence. Identity in relation to such basic questions is evidence that there are no independent forms of social consciousness, but they penetrate each other, are complementary and are branches of the same tree of knowledge of good and evil. From the foregoing, it follows in particular that religion is filled with moments of philosophy, mythology, art, science, ethics, law, and politics. Therefore not possible to determine exactly its boundaries and clearly answer the question, where religion ends and where to find the beginning of science, philosophy, morality, etc. Likewise, we cannot uniquely identify, for example, the boundaries of science - how "pure" science can be distinguished from its religious, mythological, philosophical and other components? All these modes of spirit and soul are usually combined and interrelated in the real individual's consciousness.

Nevertheless, abstract thinking helps to outline relative, conventional boundaries between different forms of social consciousness. The triad of problems philosophically stated above goes back to the main question of religion about man's connection with the Absolute. The main question of religion "in general", delivered in the most abstract form, in my opinion, consists of the following three interrelated subquestions:

1) whether there is the Absolute?

2) how one can know the Absolute?

3) how people should relate to the Absolute in practice?

Character of a particular religious connection depends strongly on the features of the solution of this main question. All principal options of religious rationality can be derived philosophically from the same question. Recognition of the fundamental question of religion allows us to subdivide "Philosophy of Religion" as academic discipline in three principle parts - ontology of religion, epistemology of religion and praxeology (or praxiology) of religion (Pivovarov, 2012-2013).

\section{References}

1. Frankl V. Osnovi logoterapii. Psihoterapiya i religiya [Principles of Logotherapy. Psychotherapy and religion]. M., 2000. P. 258.

2. Osnovi religiovedeniya [Principles of Religious studies]. Classic university textbook / Ed. By I. N. Yablokov. Moscow, 2005. P. 47.

3. Pivovarov D. V. Absolut [The Absolute] / / Contemporary Philosophical Dictionary / Editor V. E. Kemerov. London, 1998. Pp. 5-6.

4. Pivovarov D. V. Philosophiya religii [Philosophy of Religion]. In 3v. V. 1 Ontologiya religii [Ontology of religion]. Ekaterinburg: Publishing House of Ural University. 2012. 568 p.; V. 2. Epistemologiya religii [Epistemology of religion]. Yekaterinburg: Publishing House of Ural University. 2012. 556 p. V. 3. Prakseologiya religii [Praxeology religion]. Yekaterinburg: Publishing House of Ural University. 2013. 475 p.

5. Simmel G. Problemi religioznoyi pozitsii [Problem of religious position]// G. Simmel. Elected works. In 2 v. M., 1996. V. 1. P. 660. 
6. Smith J. Z. Religion, Religions, Religious // Critical Terms for Religious Studies. Chicago, 1998. P. 281.

7. Solovyov V. S. Chteniya o bogochelovechestve [Reading about the God-manhood] / / Works. In 2 v. V. 2. M., 1969. P. 5.

\section{Об универсальной дефиниции религии}

\section{Д.В. Пивоваров}

Уральский федеральный университет Россия, 620083, Екатеринбург, пр. Ленина, 51

Сопоставлены эклектика, софистика и диалектика как альтернативные научные методы определения сущности религии. Доказывается, что дефиниция В.С. Соловьева - "религия есть связь человека с Абсолютом» - универсальна и отвечает требованиям философской диалектики. Предлагается выделить уровни объективной и субъективной религиозности. Применительно к субъективной религиозности автор определяет религию как такую форму индивидуального и общественного сознания, которая сакрализует связь человека с Абсолютом. В связи с данной дефиниций формулируется основной вопрос всякой религии.

Ключевые слова: эклектика, софистика и диалектика, дефиниция религии В.С. Соловьева, Абсолют, объективная и субъективная религиозность, основной вопрос религии.

Научная специальность: 09.00.00 - философские науки. 